\title{
Vattel's Doctrine of the Customary Law of Nations between Sovereign Interests and the Principles of Natural Law
}

\author{
Francesca Iurlaro
}

\section{Introduction}

At the beginning of book II of his Law of Nations, Emer de Vattel expresses his fear that

the following maxims will appear very strange to cabinet politicians: and such is the misfortune of mankind, that, to many of those refined conductors of nations, the doctrine of this chapter will be a subject of ridicule. Be it so! - but we will nevertheless boldly lay down what the law of nature prescribes to nations. Shall we be intimidated by ridicule, when we speak after Cicero? [...] The punctual observance of the law of nature he considered as the most salutary policy to the state. ${ }^{1}$

Vattel's concerns might appear ironic to the contemporary reader, considering the immediate success of his book as the standard source for the positive law of nations. ${ }^{2}$

As a matter of fact, scholars have long insisted on the fundamental role Vattel's treatise played in the emergence ${ }^{3}$ of international law. However, more recent contributions have also emphasized the inherently normative character

1 References throughout the chapter are to the English translation of Vattel's Droit des Gens (1758) edited and with an Introduction by Béla Kapossy and Richard Whatmore: Emer de Vattel, The Law of Nations, or Principles of the Law of Nature, Applied to the Conduct and Affairs of Nations and Sovereigns, with Three Early Essays on the Origin and Nature of Natural Law and on Luxury (Indianapolis, IN: Liberty Fund, 2008).

2 On the pervasive reception of Vattel's Droit des Gens see Elisabetta Fiocchi Malaspina's chapter in this book, and her L'eterno ritorno del Droit des Gens di Emer de Vattel (secc. XVIIIXIX): L'impatto sulla cultura giuridica in prospettiva globale (Frankfurt: Max Planck Institute for European Legal History, 2017).

3 Emmanuelle Jouannet, Emer de Vattel et l'émergence doctrinal du droit international classique (Paris: Pedone, 1998). 
of Vattel's doctrine of the law of nations, by insisting on its relationship with the modern natural law tradition, embodied in the works of authors like Grotius, Pufendorf and Wolff, whose accounts Vattel challenged and discussed in the context of his own doctrinal analysis.

From this latter perspective, the present contribution seeks to address the question of the role of custom within Vattel's doctrine of the law of nations by establishing its close interconnection with natural law. In the modern age, custom became a powerful conceptual device natural law authors made use of in order to demonstrate the existence of norms which spontaneously originated from the will of European sovereigns, as a dynamic source of law situated between the demands of universality of natural law and the effectiveness required by positive law. Such an important role of custom, as both a pragmatic reality as well as a fundamental category of international relations, is one crucial, although neglected, ${ }^{4}$ feature of Vattel's legal doctrine. While seeking to fill this gap in the literature, the main claim of the present chapter is that Vattel's conceptualization of self-interest helps us to explain the role of natural law in the legitimization of the formation of custom ${ }^{5}$ according to a criterion of compliance. Notably, as Vattel claims, the foundation and compelling principle of natural law lies in the concept of self-interest, which is, in his account, the best and the safest means for securing the collective interests of nations. From this perspective, providing a close analysis of selfinterest as a basis for Vattel's theory of custom serves a double purpose. On the one hand, it helps us to understand why custom is such a powerful means to reconcile the interests of sovereign nations with collective justice. Indeed, according to Vattel, despite being based on tacit consent, the customary law of nations allows states to facilitate mutual cooperation by being clearer and more explicit about what kind of rules they want to be bound by. Promoting such a state of affairs is, in other words, one of the possible legal options states have at their disposal to pursue their own self-interest, only to find out

4 Some reference to the importance played by custom in Vattel's doctrine of the law of nations is made by Peter Haggenmacher, 'Introduction: Le modèle de Vattel et la discipline du droit international,' in Vattel's International Law from a XXIst Century Perspective / Le Droit international de Vattel vu du XXIe siècle, ed. Vincent Chetail and Peter Haggenmacher (Leiden: Brill, 2011), 1-48.

5 The distinction between the formation and the identification of the customary law of nations in Vattel is discussed below. The terms 'formation' and 'identification', commonly used in international legal scholarship, refer to the doctrinal distinction between the process leading to the formation of customary international law and its subsequent identification by the jurist. On this aspect, see M. Wood, First Report on the Formation and Evidence of Customary International Law, International Law Commission 65th Session, A/CN.4/663. 
that such interest (as well as that of other states) is best guaranteed by compliance with natural law.

On the other hand, this analysis sheds further light on the debate concerning the allegedly 'Hobbesian' foundation of Vattel's law of nations. It aims to show that, by reconceptualizing Christian Wolff's notion of perfectio in terms of self-interest, Vattel is actually making an anti-Hobbesian claim about the natural state of liberty in which all nations live. Indeed, he argues that even if such a fictional natural state of liberty did exist, nations would not mutually destroy each other, because of the likely terminal consequences of their reciprocal aspirations. They would rather be able to govern themselves exclusively through natural law precisely because custom provides states with a valid legal means to secure their individual and collective interests at one and the same time.

Although Vattel repudiates Wolff's concept of the civitas maxima, the ideal of a general society of nations nonetheless plays an important regulatory role in his doctrine of custom. He replaces Wolff's teleology of perfectio with a more pragmatic approach, which takes into account the liberty and independence of sovereign states as its fundamental, non-derogable principle.

In order to prove this, I will articulate the analysis in three sections. First of all, I will address the question of the relationship between Vattel and Wolff, to whose doctrine he explicitly refers, by pointing out both continuity and ruptures within Vattel's reception of Wolff. Secondly, I will take into account the distinction made by Vattel between the natural, the voluntary and the conventional law of nations. Custom belongs to the last legal regime, although it is closely related to natural law, as I have already pointed out. Finally, I will provide a sketch of Vattel's concept of the customary law of nations, by describing its general rules and providing examples of different cases and circumstances to which they apply.

Vattel vs. Wolff: Self-Interest as the Foundational Principle of Natural Law

As is commonly known, Vattel declaredly engages in a vulgarization of Wolff's doctrine but with some significant differences. The most relevant of them regards the question of the application of the law of nature to states. Indeed, according to Vattel, Wolff has the merit of having realized that 'the law of nature could not, with such modifications as the nature of the subjects required, and with sufficient precision, clearness, and solidity, be applied to incorporated nations or states, without the assistance of those general principles and leading 
ideas by which the application is to be directed. 6 But what exactly are 'those general principles' that should lead the application of natural law to the conduct of states? Vattel excludes the possibility of relying on a civitas maxima both as a political and as a conceptual framework through which such law can be applied. Wolff conceived of the civitas maxima as a quasi-political community of nations aimed at perfecting each other. ${ }^{7}$ Quite on the contrary, for Vattel, the fact that the principles of natural law have to be applied to states does not mean that it is necessary to coerce them into a political community, since by their natural liberty they are already gathered together to live in a natural society. ${ }^{8}$ Furthermore, Vattel argues that natural law is designed for governing human individuals, who essentially differ from nations. That is why Vattel insists on the essential feature of states, namely sovereignty, and conceives of the application of natural law to them accordingly. ${ }^{9}$

As a matter of fact, Vattel replaces Wolffian perfectio (i.e. the teleological orientation of human reason as the foundation of obligation) with self-interest. From this perspective, it has generally been argued in the literature that, by making this choice, Vattel is actually endorsing a Hobbesian view of the law of nature and, consequently, of the law of nations. ${ }^{10}$ However, on closer analysis,

6 Vattel, The Law of Nations, 10. According to Hunter, there are two senses in which the word 'application' as used by Vattel in this particular context has been interpreted by scholars. The first one is that employed by Jouannet, who implies that 'application' refers to the 'practical' application of principles. Such interpretation relies on the view that there is a presumption of general acceptance behind and justifying such application (Ian Hunter, 'Law, War and Casuistry in Vattel's Jus Gentium,' Parergon, 28/2 (2011): 92, quoting Emmanuelle Jouannet, Emer de Vattel et l'émergence doctrinale, 403-417). Another interpretation is that provided by Hunter himself; see below.

7 Christian Wolff, Jus gentium methodo scientifica pertractatum (Halle: Renger, 1749), § 10; on the concept of civitas maxima, see also Nicholas G. Onuf, 'Civitas Maxima: Wolff, Vattel and the Fate of Republicanism,' American Journal of International Law 88/2 (1994): 280303; Georg Cavallar, 'Vitoria, Grotius, Pufendorf, Wolff and Vattel: Accomplices of European Colonialism and Exploitation or True Cosmopolitans?' Journal of the History of International Law, 10/2 (2008): 181-209. Thomas Kleinlein, 'Christian Wolff: System as an Episode?' in System, Order and International Law: the Early History of International Thought from Machiavelli to Hegel, ed. Stephan Kadelbach, Thomas Kleinlein and David Roth-Isigkeit (Oxford: Oxford University Press, 2017), 216-239.

8 Vattel, The Law of Nations, 14.

9 Stéphane Beaulac, 'Emer de Vattel and The Externalization of Sovereignty,' Journal of the History of International Law, 5 (2003): 247.

10 As argued by Quentin Skinner, From Humanism to Hobbes: Studies in Rhetoric and Politics (Cambridge: Cambridge University Press, 2018); Andrew Hurrell, 'Vattel: Pluralism and its Limits,' in Classical Theories of International Relations, ed. Ian Clark and Iver B. Neumann (London: Macmillan Press 1996), 236. 
the way Vattel conceptualizes self-interest shows discontinuity rather than coherence with the Hobbesian model, in which self-interest undermines the collective goal of security and justice and only the public person of the sovereign can abstract from private self-interest to promote the common good. ${ }^{11}$

Vattel makes use of the concept of self-interest to provide natural law with a solid foundation, and jurists with a useful criterion to identify customary norms. In his words, the coercive power of natural law resides in the basic motive behind our actions, creating a situation where motives and actions coincide (which is a requirement for the fulfilment of an obligation): 'each individual has as a general and overriding motive his own self-interest, and this motive creates the obligation to which he is liable.12 The link Vattel establishes here between self-interest and obligation contradicts the Hobbesian assumption that self-interest does not provide us with an appropriate reason to comply with the law - unless one conceives of the law, as Pufendorf did, as the command of a superior. ${ }^{13}$ Vattel refutes this objection by replying 'that when we say that self-interest provides the foundation or the principle of obligation, we are speaking of a noble and agreed expediency, which is located mainly in the observance and practice of virtue - because this observance and practice brings us closer to perfection' and 'reconciles us with the good will of the Creator.' ${ }^{14}$ What Vattel means to say here is that this principle of 'noble [...] expediency' brings us closer to true perfection, insofar as it imitates the justice of God. ${ }^{15}$ This imitation produces, according to Vattel, pleasure in our action itself ${ }^{16}$ and, most notably, justice - an outcome that would not be conceivable within a Hobbesian framework.

This fundamental change of perspective on self-interest and obligation also allows Vattel to conceive of the relationship between states in a different way from Wolff: the interest of nations is to pursue their own good in a society to

11 Thomas Hobbes, Leviathan, ed. Edwin Curley (Indianapolis, IN: Hackett, 1994), 61. On the role of self-interest see Pierre Force, Self-Interest before Adam Smith: a Genealogy of Economic Science (New York: Cambridge University Press, 2003); Christopher Brooke, Philosophical Pride: Stoicism and Political Thought from Lipsius to Rousseau (Princeton: Princeton University Press, 2012), 69-75.

12 Emer de Vattel, Essay on the Foundation of Natural Law and on the First Principle of the Obligation Men find Themselves Under to Observe Laws, in The Law of Nations, 754. This essay was originally published by Vattel in his Le loisir philosophique ou pieces diverses de philosophie, de morale et d'amusement (Dresde: George Conrad Walther, 1747).

13 Samuel Pufendorf, De iure naturae et gentium libri octo (Lund: Junghans, 1672), book I, chap. I, § 3 .

14 Vattel, Essay on the Foundation of Natural Law, 762.

15 Ibid., 771.

16 Ibid. 
which they naturally belong, with no need to rely on the idea of civitas maxi$m a$. From this perspective, self-interest seems to be the most honest of collective interests: it allows a non-judgemental space in which no nation can intrude into the internal sphere of judgment of the other and, by doing so, it allows them to pursue their own national and international perfection. The perfection of self-interest ideally consists in compliance with natural law; however, it might be the case that nations do not understand this clearly, resulting in a potential conflict of sovereign interests with collective ones. Ideally, Vattel argues, self-interest, rightly understood, would not imply this kind of conflict; he admits, however, that, in reality, states often pursue what Pufendorf called 'imaginary' interests and thus seek to realize their pretensions to supremacy. ${ }^{17}$ On a more theoretical level, Vattel has faith that the interests of sovereign states should not collide with the desire to achieve justice. This claim rests on a specific view of the natural state of liberty that will be addressed in the next section. Vattel is convinced of the fact that individuals and states, if left in a state of nature, are the best version of themselves that they can be. To remember what their original condition is, one must engage in a fictional reasoning, namely to think of states as if they behaved how they are naturally supposed to do. The ultimate aim of such faith in the potentialities of sovereign states results, at the international level, in the construction of a space of peace and security.

To conclude this section, let us come back to the comparison between Vattel and Wolff: as a consequence of the way in which he proposes to apply natural law to sovereign states, Vattel's understanding of law as a perfecting device is less 'totalizing' than that of Wolff. Nonetheless, he maintains in his legal doctrine a tendency towards a higher degree of perfection, which cannot always be realized by the actual course of events but that nonetheless provides natural law with a solid principle.

Distinguished, Yet Not Treated Separately: Natural and Positive Law of Nations

Having made these clarifications, let us now move to the analysis of the impact of Vattel's reading of Wolff on his doctrine of the law of nations. Vattel divides the latter into natural (or necessary), voluntary and conventional law

\footnotetext{
17 An issue brought up by Pufendorf, who referred to this phenomenon as the 'imaginary interests of state' (Pufendorf, De jure naturae et gentium, book VIII, chap. VI, § 2).
} 
of nations (i.e. treaties and customs). In order to understand the place and importance of the customary law of nations within Vattel's doctrine, it is important to highlight the main characteristics of the law of nations as a whole. As with the 'droit des gens naturel', Vattel claims it is necessary, immutable and consists in the application of the principles of natural law to the conduct of states. ${ }^{18}$ As we have said, according to Vattel the application of natural law to nations is mediated by the concept of sovereignty and, therefore, produces two important effects. On the one hand, natural law promotes general perfection of the society of nations; on the other hand, it also has to preserve each nation's independence, equality and freedom of judgement.

The question of how Vattel seeks to reconcile these two fundamental obligations is one of the most controversial concerning his thought. ${ }^{19}$ The coexistence of these two elements - the independence of sovereign judgement and a striving for justice (an outcome of Vattel's doctrine of self-interest) generates, according to Hunter, a 'double law'.20 This double law, on the one hand, consists in the natural law of nations binding the conscience of states; on the other, it consists in the voluntary law of nations, the rules of which are deduced from natural law: 'since nations are free, independent, and equal, - and since each possesses the right of judging, according to the dictates of her conscience, what conduct she is to pursue in order to fulfil her duties, - the effect of the whole is, to produce, at least externally and in the eyes of mankind [my emphasis], a perfect equality of rights between nations, in the administration of their affairs and the pursuit of their pretensions, without regard to the intrinsic justice of their conduct, of which others have no right to form a definitive judgment; so that whatever may be done by any one nation, may be done by any other; and they ought, in human society, to be considered as possessing equal rights. ${ }^{21}$ However, as we have described, the foundation of such a voluntary law of nations is conceived of by Vattel in opposition to that of Wolff (namely, based on a principle of selfinterest rather than on mere perfectio). ${ }^{22}$ Indeed, what is relevant here is that both the natural and the voluntary law of nations are derived by Vattel from

\footnotetext{
18 Vattel, The Law of Nations, 70.

19 For a famous positivist interpretation of the Vattelian law of nations see Peter Pavel Remec, The Position of the Individual in International Law according to Grotius and Vattel (The Hague: Martinus Nijhoff, 196o).

20 Hunter, 'Law, War and Casuistry,' 92.

21 Vattel, The Law of Nations, 75.

22 Zurbuchen, 'Emer de Vattel on the Society of Nations and the Political System of Europe,' 268.
} 
nature; ${ }^{23}$ perhaps for this reason, Vattel's account of the voluntary law of nations is particularly confusing.

Instead of presenting here the various proposals for dealing with the relationship between the natural and the voluntary law of nations, ${ }^{24} \mathrm{I}$ expose what I consider to be at the origin of the difficulty in properly understanding how Vattel connected these two kinds of law of nations. This is the (unresolved Wolffian) relationship between natural law and perfectio. How should we conceive of an international society based on the dichotomy between the independence of sovereign nations and the obligation to achieve perfectio? This question is further addressed by Vattel in his Dissertation on this question: Can Natural Law Bring Society to Perfection Without the Assistance of Political Laws?25 Vattel says that 'if men were as they ought to be', natural law itself would be sufficient to bring society to perfection. ${ }^{26}$ To prove this point, he provides an interesting thought experiment:

Let us imagine one thousand people of both sexes, chosen from the most rational and virtuous in Europe, and that together they form a kind of small republic. Who can doubt that this society would not be better regulated by natural law alone, than has been any other state with the support of political laws? These one thousand people will be enlightened enough to get to know natural law, and to be convinced that their best interest requires that they conform to it exactly. As a result, their society will be as perfect a human society as any such can. They will have a body of law, just, wise, and complete, which is known to all the members and accompanied by sufficient incentives to shape their will. Without the need for subordination to the authority of a government, they will acknowledge themselves under the obligation of this law that they derive from nature to provide for the common good. They will focus their talents and labor on this goal; everyone will compete to preserve order and peace.

\footnotetext{
23 Ibid.

24 On the debate concerning Vattel's natural and voluntary law of nations, see Haggenmacher, 'Introduction: Le modèle de Vattel et la discipline du droit international'; Remec, The Position of the Individual; Gabriella Silvestrini, 'Justice, War and Inequality. The Unjust Aggressor and the Enemy of the Human Race in Vattel's Theory of the Law of Nations,' Grotiana, 31 (2010): 44-68; Charles Covell, The Law of Nations in Political Thought: A Critical Survey from Vitoria to Hegel (New York: Palgrave Macmillian, 2009), 95-106.

25 A translation of this essay, originally published by Vattel in his Le loisir philosophique ou pieces diverses de philosophie, de morale et d'amusement (Dresde: George Conrad Walther, 1747), can be found in Vattel, The Law of Nations, 773-781. 
If differences arise, they will choose arbitrators to resolve them. And if it should happen that one individual, possessed by the force of a violent passion, departs from his duty, then the others, whose reason would not be obscured by the same clouds, would they not readily and with one will restrain him without provoking the least social dislocation? Some might vainly object that regulations would be required for trade, for example, or for crucial periods of war and epidemic disease, and a sovereign authority to ensure that they are observed. But reason will promote wise measures in these instances to the people as we have imagined them, and natural law will oblige them to preserve those rules devotedly, as they will tend to social benefit. But men are very different from what they ought to be and from these one thousand people of whom we have just spoken. ${ }^{27}$

People do not always know the real content of natural law and are not that well informed of the fact that their interests are better pursued by compliance with natural law. Thus, according to Vattel, the answer to this problem is to 'extend the knowledge of natural law by making its application easy, and as a result reducing it to clearly publicized general rules' and to establish 'public authority, and adding a positive obligation to natural obligation, through the means of punishment. ${ }^{28}$ This passage recalls the paragraph in the Law of Nations in which Vattel says that we ought 'to produce, at least externally and in the eyes of mankind [my emphasis], a perfect equality of rights between nations'. Publicity is what helps us achieve this goal. Therefore, Vattel says, 'in the current condition of the human race, natural law cannot bring society to perfection without the assistance of political laws'.29 This statement seems to imply for Vattel that, whereas the possibility of an international legal order governed by a self-legislating natural law sounds unfeasible in his particular historical moment, this does not prevent us from knowing that we are in principle capable of that. To understand this, we must engage in some fictional reasoning, by thinking of human beings as if they were in their natural state of liberty; additionally, we should promote the signing of agreements among nations to secure their reciprocal rights.

As we briefly mentioned above, besides the natural and the voluntary law of nations, Vattel introduces yet another kind of law of nations, that is, conventional law, to which treaties and custom belong. Interestingly, for Vattel, custom plays a fundamental connecting role between the voluntary law of nations

\footnotetext{
27 Vattel, Dissertation, in The Law of Nations, 777.

28 Ibid., 779 .

29 Ibid.
} 
(which comprises the rules indicating what nations need to tolerate between them in order to respect each other's sovereignty and independence) and treaties (as proactive means to secure the interests of states and the scope of what they can demand from others).

Whereas treaties rely on express consent, custom is based on tacit consent. However, Vattel conceives of tacit consent in an innovative way. The fact that it is tacit refers to its formation, but not to its identification: in other words, nations are invited to publicly express with political statements whether they wish to be bound or not by a given custom and to turn them into treaties (see above: according to publicity and promotion). Additionally, Vattel says he will lay down only some 'general rules' that nations are bound to respect with regard to conventions (treaties and customs), ${ }^{30}$ as I will show in the next section.

To conclude, Vattel adds that the voluntary and the conventional law of nations, taken together, can be called the positive law of nations. Positive law must be distinguished, but not treated separately from, natural law: the two often overlap, but sometimes they do not. While positive law should not be confused with natural law, the latter has nevertheless to remain the guiding principle. By so doing, it assures the normative character of the law of nations as a whole. However, the following question arises: how is it then possible to judge the rightness of a conventional law (a treaty or a custom) if no nation is allowed to judge the other? First of all, it is precisely the content of natural law (the general rules of promoting perfection and, yet, respecting sovereign independence of judgement) that provides us with a valid criterion by which to understand whether customary rules are compliant with natural law. Secondly, Vattel solves this problem by conceding a fundamental importance to public statements: through them, nations 'activate' their rights - as is particularly evident in the customs of war, especially those concerning the declaration of war. ${ }^{31}$ Vattel's customary law of nations consists precisely in a series of unilateral acts producing effects on others: nations, by stating, refusing or applying certain rules without necessarily demanding their respect from others, guarantee themselves freedom and independence, since this secures them from being attacked (and from being the object of intrusive judgement of other nations). Vice versa, as we will see, there are customs originating from perfect rights which are binding on the parties involved - unless they opt out in due time.

$30 \quad$ Vattel, The Law of Nations, 77.

31 Silvestrini, 'Justice, War and Inequality,' 59; on regular war in Wolff and Vattel, see also Pablo Kalmanovitz, 'Sovereignty, Pluralism, and Regular War: Wolff and Vattel's Enlightenment Critique of Just War,' Political Theory 45 (2017): 1-24. 
Although the question of Vattel's method is particularly problematic, ${ }^{32}$ I think that it provides us with some useful insights into the question of custom in Vattel. Also, as we have seen, it is difficult to imagine a completely positive Vattelian law of nations, and we have emphasized its core normative elements. However, my claim is that in Vattel a normative claim about the law of nations coexists with a pragmatic method to assess its content, as he says that natural and positive law must be distinguished but not separated. This is particularly relevant for Vattel's doctrine of custom, which contains a coexistence of normative judgements and practical considerations. Vattel investigates the tension between practice and principles mostly by looking at the historical record. He makes massive use of the works of national historiographers and memorialists to support his arguments and, quite differently from his predecessors, he expresses here and there his scepticism towards classical history, which is no longer conceived of as the repository of perfect and generally accepted behaviours, as it was in Gentili or Grotius before him. ${ }^{33}$ Vattel contrasts the errors of a past, which is now perceived as far away, with the vivid descriptions of contemporary historians and memorialists. ${ }^{34}$ This is an interesting aspect, reflecting the changes in the historical discipline, from an erudite source of knowledge to a first-person description of events, where accuracy is less important than direct witness of and involvement in the facts narrated (Vattel himself is author of several Mémoires). ${ }^{35}$ However, it is worth pointing

32 Vattel's method has been described as the application of general normative principles to the study of singular cases of the law of nations. The relationship between the normativity of the principles of natural law and their pragmatic application to concrete situations is what makes the Vattelian method problematic, to the point that Ian Hunter has even spoken of a 'casuistic method'. See Ian Hunter, 'Vattel's Law of Nations: Diplomatic Casuistry for the Protestant Nation,' Grotiana 31 (2010): 108-109; see also Luke Glanville, 'Responsibility to Perfect,' 389; Stefan Oeter, 'Neutrality and Alliances,' in Vattel's International Law, 336-337.

33 On the role of historical examples in Alberico Gentili's doctrine of ius gentium, see Francesca Iurlaro, 'The burden of reason. Ratio probabilis, consensio omnium and the impact of humanitas on Alberico Gentili's theory of customary international law,' History of Political Thought 38 (2017): 409-438; on the same topic in Grotius, see Benjamin Straumann, Roman law in the state of nature: The Classical Foundations of Hugo Grotius' Natural Law (Cambridge: Cambridge University Press, 2015).

34 On the importance of official historiography for modern political discourse, starting from Samuel Pufendorf, see Pärtel Piirimäe, 'Official Historiography and the State in Early Modern Europe,' Storia della storiografia 71/1 (2017): 47-75.

35 See for example Mémoires pour server à l'histoire de notre tems, par l'Observateur hollandois [Jacob-Nicolas Moreau], rédigez et augmentez par M. D. V [Emer de Vattel] (Frankfurt 
out an evolution in Vattel's own thought: whereas he makes moderate use of examples in the 1758 edition, he provides more examples in the revisions he drafted and these were included in the posthumous editions of his work. This might suggest an increasing need, perceived by the author, to provide the reader with examples: although they are not substantial to the argument, as he points out many times, they nonetheless provide for us a precious source of information on historical customary behaviours which he conceived of as established practice.

Three main claims are made in this section. First of all, whenever possible, Vattel seeks to provide a conciliation of principles of natural law and state practice. Historical analysis is particularly helpful in this respect. This coincidence between facts and principles shows Vattel's normative commitment (subordinated to the structure and divisio iuris we described above) as well as his need to give instructions to 'cabinet politicians' about customs. This scenario perfectly fits the 'ideal' situation described above, in which states are pursuing their own self-interest by complying with natural law. Secondly, by doing so, Vattel implicitly distinguishes between the process of formation of custom and that of identification: whereas the fact that a custom has received acceptance depends on its compliance with natural law, its identification is a distinct, pragmatic activity in which the jurist or the politician is engaged in his daily life. Therefore, and thirdly, whenever facts and principles do not coincide, Vattel provides us with a useful set of tools in order to identify and detect customs. He calls them 'general rules of custom' and he refers to historical analysis for particular occurrences of custom. From the reading of Vattel's text it is possible to extract three general rules to identify international customs: for each of them I will provide an example, which will also help us to understand the nature and functioning of Vattel's pragmatic-historical method.

Already in the Preface to his Law of Nations, Vattel anticipates the importance of custom, ${ }^{36}$ but it is in his Preliminaries that he gives us a full account of what he means by 'customary law of nations', i.e. a 'law founded on a tacit consent, or, if you please, on a tacit convention of the nations that observe it towards each other' ${ }^{37}$ As Wolff did, Vattel also emphasizes the importance of custom as a particular source of law (as opposed to the universality of

and Lepizig: aux dépens de la compagnie, 1757); Mémoires pour servir à l'histoire de notre tems, par rapport à la guerre anglo-gallicane, par l'Observateur hollandois [JacobNicolas Moreau], rédigez et augmentez par M. D. V. [Emer de Vattel], 2 vols. (Frankfurt and Leipzig: aux dépens de la compagnie, 1757-1758).

36 Vattel, The Law of Nations, 'Preface,' 17.

37 Ibid., 77 . 
voluntary and natural law of nations). The regionalism of custom ${ }^{38}$ seems to restrict the application of customs to the European civilized nations, by constructing a unitary source of obligation that automatically excludes nonEuropean customs. ${ }^{39}$ However, together with the customs adopted by certain specific nations (like those concerning the formalities of the declaration of war), Vattel also mentions 'universal customs' with reference to a specific aspect of the laws of embassy, as we will see. It seems, therefore, that there are different degrees of application of custom, of course depending on whether they coincide with principles and on whether they seek to regulate fundamental values of the international order, like the independence of sovereign states. Also, regional customs seem to be for Vattel particular applications of general principles which are now settled as practice; universal customs are, rather, the customary expression of the principles of natural law (like that of sovereign authority, as we will see).

Consistent with these questions, the analysis in this section seeks to extract from Vattel's Law of Nations some general rules concerning the formation and identification of custom which he presents in his examples. These rules concern, as he writes in the above-mentioned passage, both the general functioning of custom and the way to assess its legality and compliance with natural law. It is possible to identify three situations. The first one, in which Vattel claims that there is a convergence of facts and principles, corresponds to the ideal situation, in which nations behave how they should do. In this case, customs are inherently compliant with natural law. However, there might be cases of non-compliance and, in order to avoid such episodes, he suggests that such customs are turned into treaties, in order to make them perfectly enforceable.

Vattel introduces a second category of customs, those which are by their nature 'indifferent' as far as their content is concerned, since they originated from the liberty and will of nations. In this second case, the question of compliance with natural law is not of primary importance, unless customs are manifestly against the law of nature, but in that case they would no longer be indifferent. In this case, Vattel provides us with three methods of identification of customs, consistent with the structure of his legal doctrine: a criterion

38 Haggenmacher, 'Introduction,' has emphasized the 'regional' character of custom in Vattel.

39 On Rech's pluralist reading of the pre-Vattelian tradition of custom, see Rech, Enemies of Mankind, 124; also, on 'intra-European' custom see Ian Hunter, 'The Figure of Man and the Territorialisation of Justice in Enlightenment Natural Law: Pufendorf and Vattel,' Intellectual History Review 23/3 (2013): 289-307; Hurrell, 'Vattel: Pluralism and its Limits,' 235 . 
of non-indifference (similar to but not to be confused with the contemporary doctrine of opinio iuris), acknowledgement by public statement and by violation.

In addition to this, he addresses a fundamental problem: is the violation of custom punishable? The answer to this question will call into question once again the distinction between internal and external obligations and perfect and imperfect rights.

\section{Facts with Meaning: Customs Originating in an} Overlapping of Practice and Principles

The overlapping of facts and principles is a characteristic of most of the customary norms mentioned by Vattel. Such an account of custom, normative and pragmatic at the same time, might have been influenced by Cornelius Bynkershoek, who is frequently quoted in the Law of Nations. He claimed, in his De foro legatorum (1721), that custom is made of ratio and usus. Reason is what gives meaning to mere usus, namely practice based on repetition. ${ }^{40}$ I will here provide two examples of overlapping of facts and principles, one concerning the custom of declaring war and the other concerning the neutrality of commerce.

Declaration of war is an essential moment of Vattel's doctrine of war in due form. ${ }^{41}$ In this respect, 'it is necessary that the declaration of war be known to the state against whom it is made. This is all which the natural law of nations requires. Nevertheless, if custom has introduced certain formalities in the business, those nations, who, by adopting the custom, have given their tacit consent to such formalities, are under an obligation of observing them, as long as they have not set them aside by a public renunciation. ${ }^{42}$ Here Vattel precisely hints at the 'regionalism' of customary formalities concerning declaration of war, and he also introduces a fundamental characteristic of custom. Vattel thinks that declaration of war is required by the natural law of nations (as a way of making the intentions of sovereigns explicit and, therefore,

40 As claimed by Kinji Akashi, Cornelius van Bynkershoek: His Role in the History of International Law (The Hague: Kluwer Law International, 1998), 37. The reference to Bynkershoek is explicit in book IV of The Law of Nations, 736, where Vattel discusses the laws of embassy regarding the liability of the ambassador in cases of lawsuits.

41 As it marks the exit from the natural law of nations and the entry into a consensual regime of the voluntary law of nations, as argued by Silvestrini, 'Justice, War and Inequality,' 6o. 
accountable), whereas formalities are the object of custom. In order to activate such customs, nations can respect them, or opt out from them with a public statement, or even violate them, as we will see. What is more important is that an internal obligation is turned into a perfect one by statement or action (not necessarily by turning it into a treaty). Nations shall manifest their intentions, based on their unquestionable judgement, so that other nations know how to behave and, most importantly, how the natural law of nations applies to their conduct. A similar example concerns the meaning of the declaration:

When the sovereign or ruler of the state declares war against another sovereign, it is understood that the whole nation declares war against another nation: for the sovereign represents the nation, and acts in the name of the whole society [...]; and it is only in a body, and in her national character, that one nation has to do with another. Hence, these two nations are enemies, and all the subjects of the one are enemies to all the subjects of the other. In this particular, custom and principles are in accord. ${ }^{43}$

Another example is that of the relationship between war and commerce. During the Seven Years' War the question of neutrality of commerce was particularly urgent because the idea started to emerge that if the trade of an allegedly neutral nation was supporting one of the nations at war, then this would be contrary to the law of nations. ${ }^{44}$ Vattel asserts that the issue needs to be addressed by distinguishing between neutral goods and military goods: whereas it would be a violation of the law of nations to forbid the first, innocent kind of commerce, it would be legitimate to forbid the second one, which constitutes a breach of neutrality. However, Vattel says that the prevailing custom in his own time is to avoid whenever possible the intrusion of neutral nations into the commercial affairs of an enemy nation. ${ }^{45}$ However, how should we treat those who help our enemies? They are in principle enemies as well, and therefore we can ask them to account for their conduct. However, Vattel suggests that this right is exercised with prudence, as it might cause more problems than it might solve. ${ }^{46}$ Additionally, 'if prudence dissuades us from making use of

43 Ibid., 509 .

44 For example, see contributions in War, Trade and Neutrality. Europe in the Mediterranean in the seventeenth and eighteenth centuries, ed. Antonella Alimento (Milano: Franco Angeli, 2011); Oeter, 'Neutrality and Alliance'; Tara Helfman, 'Neutrality, the Law of Nations and the Natural Law Tradition: A Study of the Seven Years' War,' Yale Journal of International Law 30/2 (2005): 549-584.

45 Vattel, The Law of Nations, 511.

46 Ibid., 518-519. 
all our right, it does not thereby destroy that right. A cautious nation chooses rather to overlook certain points than unnecessarily to increase the number of her enemies.' ${ }^{47}$ This hints at the fictional character of custom, as a 'virtual' set of rules that needs to be activated (but the existence of which is not dependent on such activation). On the contrary, if nations made use of such right too often, 'the contrary principles would tend to multiply wars, and spread them beyond all bounds, to the common ruin of nations. It is happy for Europe, that, in this instance, the established custom is in accord with the true principles'.48

Another circumstance arises when a supposedly neutral nation engages in illicit trade with another nation's enemy: if the situation occurs, do nations have a right to confiscate such contraband goods? Vattel contends that 'barely to stop those goods would in general prove an ineffectual mode'; therefore, nations should 'prevent, as far as possible, the enemy's being supplied with such articles as will add to his strength and render him more dangerous, that necessity and the care for her own welfare and safety authorize her to take effectual methods to that purpose, and to declare that all commodities of that nature, destined for the enemy, shall be considered as lawful prize. ${ }^{49}$ The better method to achieve this purpose is for a nation to notify the neutral states of its declaration of war, 'whereupon, the latter usually give order to their subjects to refrain from all contraband commerce with the nations at war, declaring that if they are captured in carrying on such trade, the sovereign will not protect them'. Vattel claims that this rule seems 'at present' to have crystallized as 'the general custom of Europe, 50 and quotes as authoritative sources in support both Grotius ${ }^{51}$ as well as two ordinances of the kings of France, issued in 1543 and $1584^{52}$

Vattel's passage is quite explicit about what happens before a custom becomes a generally established practice: there might be a number of variations, eventually resulting in the current state of events, where a particular custom is introduced (which historical analysis might even help us to date: as with the example of France quoted above). Vattel further says that the custom in question is most 'suitable and compliant with principles of natural law'.53 At the same time, he specifies that this current state of affairs is the result not only of

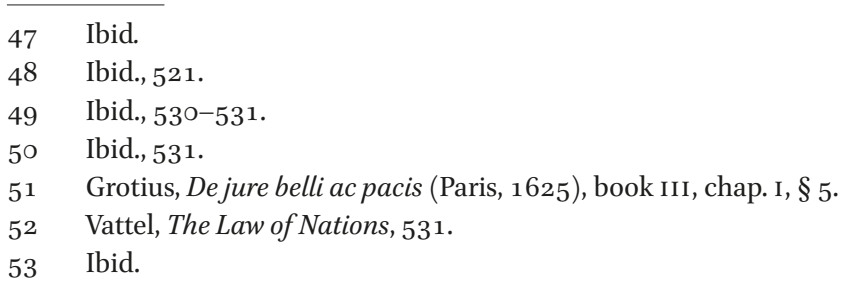


past modifications but also of possible future ones ('this rule is the point where the general custom of Europe seems at present fixed'). However, following his argument, it is hard to imagine that a custom so coincident with both 'mutual duties of nations' and their respective rights could change in time without causing a violation of the principles of natural law it is so agreeable to. This tension might be interpreted, on the one hand, as an instance of regionalism, i.e. a particular external expression, in a given context and time, of a normative principle, which crystallizes over time with no further need of modifications once it is fixed. Such an 'evolutionary' interpretation might pose the problem of considering custom as natural law, and by so doing confusing the two legal regimes (an option which Vattel warns us not to choose). On the other hand, it is possible to argue that the 'present custom' is the best possible option that, in the current state of events, nations can strive for, but that it does not exclude even better applications of the same principles it expresses. This interpretation seems in line with Vattel's thought experiment of the wise 1,00o Europeans governing themselves by only applying natural law: that situation is not a cosmopolitan ${ }^{54}$ society to strive for, but the natural state of affairs of men, if only they were as they are supposed to be. If the custom at stake is agreeable to that natural state of affairs, then it might be interpreted as the best 'external' approximation of the natural law of nations.

To conclude this section, it is also worth mentioning that Vattel suggests that instances of violations are nothing but confirmations of customs. ${ }^{55}$ For example, the person of ambassadors is inviolable by the universal custom and consent of nations', and although Vattel acknowledges that there have occurred some instances to the contrary, 'a few facts do not establish a custom: on the

54 According to Hunter, "The actual practice of abstraction through which Vattel "applies" the natural law to the conduct of nations is thus not one in which he makes the maxims of the latter conform to the principle of the former, or else fails to. Rather it is one in which he deploys both principles in order to structure a specialized practice of judgment. Here it is the difficulty of applying the cosmopolitan principle of natural law to the self-interested conduct of nations that is used to admit a whole series of accommodationist maxims and conventions - the voluntary law of nations - that are to be regarded nonetheless as if they were imperfect approximations of natural law cosmopolitanism' (Hunter, 'Law, War and Casuistry,' 94). In my view, according to what I called Vattel's fictional reasoning of considering men perfect, as they would be if they were following natural principles, they should be, rather, looked at as perfect (although maybe temporary) rather than imperfect approximations of natural law cosmopolitanism.

55 Interestingly, a doctrine also acknowledged by contemporary international law, as famously expressed by the International Court of Justice in 1986 (Military and Paramilitary Activities in and against Nicaragua, Nicaragua v. United States of America, Merits, Judgment, I.C.J. Reports 1986, para. 186). 
contrary, those to which I allude, only contribute, by the censure passed on them, to prove the custom such as I have asserted it to be. ${ }^{56}$

Finally, acknowledgement by violation is nothing but a reinstatement of the doctrine of the overlapping of facts and principles. To support his claim, Vattel here refers to Bynkershoek: 'it may be seen, in monsieur de Bynkershoek's treatise, that custom coincides with the principles laid down in this and the preceding section. In suing an embassador [...] the embassador is to be summoned in the same manner as an absent person, since he is reputed to be out of the country, and his independency does not permit any immediate address to his person in an authoritative manner, such as sending an officer of a court of justice to him.57

This is the first rule established by Vattel:

When a custom or usage is generally established, either between all the civilized nations in the world, or only between those of a certain continent, as of Europe, for example, or between those who have a more frequent intercourse with each other, - if that custom is in its own nature indifferent, and much more, if it be useful and reasonable, it becomes obligatory on all the nations in question, who are considered as having given their consent to it, and are bound to observe it towards each other, as long as they have not expressly declared their resolution of not observing it in future. But if that custom contains anything unjust or unlawful it is not obligatory: on the contrary, every nation is bound to relinquish it, since nothing can oblige or authorize her to violate the law of nature. ${ }^{58}$

An interesting parallel is offered by Vattel when he writes, in his Essay on the Foundation of Natural Law, that natural law cannot be indifferent: 'from there it follows that natural law is universal. Since it requires us to do all that is most suited to our nature, there is no situation in which it can let us down; for in every situation in which there is a better option to take, we are ordered to take it; and if it were possible to find a case of perfect indifference, no law would be of any use in resolving the matter.59 If natural law provided us with a case

56 Vattel, The Law of Nations, 73 .

57 Ibid., 736.

58 Ibid., 78.

59 Vattel, 'Dissertation,' in The Law of Nations, 775. 
of perfect indifference, no law would serve as a criterion, since it is only natural law to prescribe for us what is more suitable to our nature (through selfinterest as the principle of obligation).

Vattel provides an application of what we will call a 'fictional criterion of non-indifference' in his book IV, on the law of embassy:

and it must be observed here, with regard to things of institution and custom, that, when a practice is so established, as to impart, according to the usages and manners of the age, a real value and a settled signification to things which are in their own nature indifferent, the natural and necessary law of nations requires that we should pay deference to such institution, and act, with respect to such things in the same manner as if [my emphasis] they really possessed all that value which the opinion of mankind has annexed to them. ${ }^{60}$

In other words, Vattel suggests that a counterfactual reasoning be applied in cases of normative indifference of a given custom. From this mental experiment, we are able to assess that the normative value of a customary rule is not directly derived from the principles of natural law but rests on a generally accepted opinion of mankind which makes such custom meaningful. Of course, this does not mean that 'indifferent customs' can be inconsistent with natural law: rather, Vattel just suggests that the interpreter distinguishes among different sources of obligation.

Another question addressed by Vattel is the issue of the abrogation of custom. He admits that it is possible for a nation to opt out from a custom before the moment of its application. In his words, 'if, in process of time, any nation perceives that such custom is attended with inconveniences, she is at liberty to declare that she no longer chooses to conform to it: and when once she has made this explicit declaration, no cause of complaint lies against her for refusing thenceforward to observe the custom in question. But such a declaration should be made beforehand, and at a time when it does not affect any particular nation' ${ }^{61}$

In this example, the difference between formation and identification is more evident. The fact that custom is a tacit and 'virtual' legal regime does not mean that nations are a society of mute legal subjects: quite on the contrary, since it is unfeasible that they are governed by natural law alone, they have to publicly state their position and promote the signing of positive agreements (through

6o Vattel, The Law of Nations, 695 .

61 Ibid., 724. 
which they can reciprocally demand rights of one another). Also, the fact that the content of custom is normatively indifferent allows us to change it over time.

However, the question once again arises of whether it is possible for sovereigns to opt out from all kinds of customs. Universal customs, like those concerning the inviolability of ambassadors, seem to be more cogent than 'particular ones'. Vattel provides an example of such universal customs, directly deriving from the natural law of nations: to prove his point, he quotes a number of instances of non-European nations respecting them (Chinese, Mexicans, North-American tribes, etc.). ${ }^{62}$ By so doing, he seeks to prove the general acceptance of this customary rule by insisting on the cultural value that various and diverse nations have annexed to it.

Interestingly enough, the following passage concerning the inviolability of the ambassador is supplied with historical examples, although Vattel declares that they do not add any content to the rule, but that he uses them just for the sake of explanation. However, historical examples are more abundant each time that Vattel is not explicitly making the claim that facts coincide with principles. This might suggest that history is essential in ascertaining the value and opinion that 'mankind has annexed' to a given custom, whereas in cases of factual overlapping of custom with principles it aims at helping the jurist to deduce law from facts, by tracing back their first occurrence in time. The choice of historical sources is particularly innovative, if compared with those of Vattel's predecessors: French historians like François-Eudes Mezeray and Abbé de Choisy ${ }^{63}$ are quoted, as well as Simon Ockley's History of the Saracens. ${ }^{64}$ All these historiographic references show that the rationale behind the privileges to be granted to ambassadors is that it is better to leave an ambassador unpunished than to violate his immunity: therefore, it is better to overlook such instances of violation than to put at risk the necessity of nations to communicate and to carry on negotiations.

\section{Is the Violation of Custom Punishable?}

The possibility of punishing the violation of a customary rule depends on different factors. Most importantly, as a general rule and consistently with his

62 Ibid., 721.

63 Vattel, The Law of Nations, 722.

64 On the eighteenth-century development of the historical disciplines, as well on memorialists, see Chantal Grell, Pratiques et Concepts de l'Histoire en Europe XVIème-XVIIIème siècles (Paris: Presses de l'Université de Paris-Sorbonne, 199o). 
theoretical assumptions, Vattel seems to suggest that such decision calls into question the requirement of compliance with natural law: will such punishment impair the sovereign's search for perfection and independence of judgement? In principle, therefore, violation of custom is not punishable for Vattel. This is particularly evident the case of moderation to be applied in the treatment of hostages, which is, according to Vattel, a custom of nations, settled in practice. Its violation, although repugnant to the law of nature, cannot always be punished: indeed, 'all that [the violation of] such a custom can produce, is impunity among the nations who practise it. Whoever is guilty of it cannot complain that another is so too: but every nation may and ought to declare, that she considers the action as a barbarity injurious to human nature. ${ }^{65}$ As we have stated before, nations can publicly state their position on a given issue, by respecting, violating or expressing their support for a given custom. As a general rule, therefore, only violations of the voluntary law of nations (which rests on the presumed consent of nations) are collectively enforceable, subject to certain conditions and moderation. However, as discussed by Toyoda, Vattel writes, in a letter to Brühl, that there is a passage in his Law of Nations justifying a collective intervention by European nations to punish Frederick of Prussia for having introduced those 'sinister customs of war' (i.e. the invasion of Saxony with no declaration of war) ${ }^{66}$ In this case, we can argue that we are dealing with different customs: the one concerning the declaration of war directly stems from natural law and calls into question the justice of the cause, which substantiates itself in the conduct of a regular war. The Prussian invasion of Saxony does not seem to meet these requirements, as the purpose of declaring war is to inform neighbouring states about one's own intentions, once all the peaceful methods of dispute settlement have been exhausted. Furthermore, Frederick's act may introduce, if imitated by other countries, a sinister custom of war and therefore it might be right to intervene against him. In other words, this example shows a conflict between custom and sovereign judgement. How do we respond to a violation of custom when, in order to do so, we have to massively intrude into another sovereign's judgement? This aspect is controversial because it implies, on the one hand, the relationship between states vis-à-vis states and, on the other, it calls into question the problem of Vattel's account as politically loaded. ${ }^{67}$

65 Ibid., 115 .

66 Tetsuya Toyoda, Theory and Politics of the Law of Nations: Political Bias in International Law Discourse of Seven German Court Councilors in the Seventeenth and Eighteenth Centuries (Leiden: Martinus Nijhoff Publishers, 2011), 170.

Ibid. 
Quite on the contrary, the custom of moderation in war does not concern the relationship between states and other states but between states and individuals: it does not imply judgement about the justice of the war (duties of justice), but rather a general duty of moderation that sovereigns have to follow (duties of humanity). In Vattel's words, compassion towards a prisoner is a custom, but if a sovereign cannot comply with it for reasons of force majeure, he may not be charged with violating the laws of war. ${ }^{68}$ Again, Vattel provides historical examples of moderation, taken from contemporary history rather than from Roman history. This is quite original, because for early modern jurists Roman leaders were examples of pietas and clementia - a myth that Vattel seems not to be fascinated by. Indeed, ancient customs about the treatment of prisoners were wrong because they permitted their death: Vattel suggests that contemporary customs, instead, especially those of civilized countries like England or France, are far better than those of the ancients. ${ }^{69}$

Unlike universal customs, regional customs can be enforced, because they are more formalities than customary rules (they are similar to our contemporary 'acts of courtesy'). As an instance of this, Vattel quotes the example of the honours due to ambassadors: the usage of receiving an ambassador wearing a hat, for instance, is a sign of deference due to his persona as a representative of the sovereign. To make this point, Vattel mentions that in 1663 ambassadors from Switzerland 'suffered the king of France, and the nobles of his court, to refuse them those honours which custom has rendered essential to the embassadors of sovereigns, and particularly that of being covered before the king at their audience. ${ }^{70}$ Later on, when Louis XV visited Alsace in 1755 , the Swiss sent no ambassadors precisely because their 'just demand' had been rejected. Again, the partiality of Vattel's example is itself insufficient to claim that there was a general acceptance of such custom; however, it makes the position of Switzerland clear on this issue.

To conclude, and to avoid problems related to punishment, Vattel suggests that on many occasions that it is wiser for nations to turn customs into treaties. For example, a nation which by long custom trades with another one (such as Portugal selling wine to England) and 'desires any right of commerce which shall no longer depend on the will of another, she must acquire it by treaty'71 Also, usucapion and prescription are examples of customs which Vattel suggests should be turned into treaties, but, 'if, in default of treaties, custom has

68 Vattel, The Law of Nations, $55^{1 .}$

69 Ibid., 553.

70 Ibid., 695 .

71 Ibid., 137. 
determined anything in this matter, the nations between whom this custom is in force, ought to conform to it. ${ }^{72}$ This passage shows that Vattel does not think of custom as an insufficient source of obligation; he just argues that for vital matters - those relating to the life of a state - sovereign interests are better secured by the signing of a treaty.

\section{Conclusion}

To conclude this contribution, it is worth further emphasizing that Vattel's doctrine of the law of nations is a constant restatement of the fact that relying on self-love is the best means for realizing collective interests. The fairer, more public and explicit are the rules of the international 'game', the better will be the outcome. In this perspective, custom plays a crucial role, in at least three respects. First of all, it clarifies the relationship between natural law and positive law, by insisting on the fact that, as a source of law, custom is both compliant with natural law and effective as positive law. Secondly, another important element is Vattel's insistence on the added value that nations annex to custom, which would otherwise be nothing but a mere usus, carrying no legal meaning or obliging force whatsoever. Quite on the contrary, Vattel manages to bind the persuasive force of custom into compliance with natural law and, ultimately, with the pursuit of self-interest. Thirdly, and finally, Vattel's concept of custom calls into question the idea of an international legal order where normative principles coexist with practical considerations of expediency, an aspect which makes such theorization particularly illuminating even for contemporary debates concerning customary international law. ${ }^{73}$

\section{Bibliography}

Akashi, Kinji, Cornelius van Bynkershoek: His Role in the History of International Law (The Hague: Kluwer Law International, 1998).

Alimento, Antonella (ed.), War, Trade and Neutrality. Europe in the Mediterranean in the seventeenth and eighteenth centuries (Milano: Franco Angeli, 2011).

Beaulac, Stéphane, 'Emer de Vattel and The Externalization of Sovereignty,' Journal of the History of International Law 5 (2003): 237-292.

72 Ibid., $337-338$.

73 I would like to acknowledge and thank Simone Zurbuchen and Gabriella Silvestrini for providing insightful and stimulating comments on an early draft of this chapter. 
Brooke, Christopher, Philosophical Pride: Stoicism and Political Thought from Lipsius to Rousseau (Princeton: Princeton University Press, 2012).

Cavallar, Georg, 'Vitoria, Grotius, Pufendorf, Wolff and Vattel: Accomplices of European Colonialism and Exploitation or True Cosmopolitans?' Journal of the History of International Law 10/2 (2008): 181-209.

Covell, Charles, The Law of Nations in Political Thought: A Critical Survey from Vitoria to Hegel (New York: Palgrave Macmillian, 2009).

Fiocchi Malaspina, Elisabetta, L'eterno ritorno del Droit des Gens di Emer de Vattel (secc. XVIII-XIX): L'impatto sulla cultura giuridica in prospettiva globale (Frankfurt: Max Planck Institute for European Legal History, 2017).

Force, Pierre, Self-Interest before Adam Smith: a Genealogy of Economic Science (New York: Cambridge University Press, 2003).

Glanville, Luke, 'Responsibility to Perfect: Vattel's Conception of Duties Beyond Borders,' International Studies Quarterly 61 (2017): 385-395.

Grell, Chantal, Pratiques et Concepts de l'Histoire en Europe XVIème-XVIIIème siècles (Paris: Presses de l'Université de Paris-Sorbonne, 1990).

Haggenmacher, Peter, 'Introduction: Le modèle de Vattel et la discipline du droit international,' in Vattel's International Law from a XXIst Century Perspective / Le Droit international de Vattel vu du XXIe siècle, ed. Vincent Chetail, Peter Haggenmacher (Leiden: Brill, 2011), 1-48.

Helfman, Tara, 'Neutrality, the Law of Nations and the Natural Law Tradition: A Study of the Seven Years' War,' Yale Journal of International Law 30/2 (2005): 549-584.

Hobbes, Thomas, Leviathan, ed. Edwin Curley (Indianapolis, IN: Hackett, 1994).

Hunter, Ian, 'Law, War and Casuistry in Vattel's Jus Gentium,' Parergon 28/2 (2011): 87-104.

Hunter, Ian, 'The Figure of Man and the Territorialisation of Justice in Enlightenment Natural Law: Pufendorf and Vattel, Intellectual History Review 23/3 (2013): 289-307.

Hunter, Ian, 'Vattel's Law of Nations: Diplomatic Casuistry for the Protestant Nation,' Grotiana 31 (2010): 108-140.

Hurrell, Andrew, 'Vattel: Pluralism and its Limits,' in Classical Theories of International Relations, ed. Ian Clark and Iver B. Neumann (London: Macmillan Press 1996), 233255.

Iurlaro, Francesca, 'The burden of reason. Ratio probabilis, consensio omnium and the impact of humanitas on Alberico Gentili's theory of customary international law,' History of Political Thought 38 (2017): 409-438.

Jouannet, Emmanuelle, Emer de Vattel et l'émergence doctrinal du droit international classique (Paris: Pedone, 1998).

Kalmanovitz, Pablo, 'Sovereignty, Pluralism, and Regular War: Wolff and Vattel's Enlightenment Critique of Just War', Political Theory 45 (2017): 1-24.

Kleinlein, Thomas, 'Christian Wolff: System as an Episode?' in System, Order and International Law: the Early History of International Thought from Machiavelli to Hegel, 
ed. Stephan Kadelbach, Thomas Kleinlein and David Roth-Isigkeit (Oxford: Oxford University Press, 2017), 216-239.

Military and Paramilitary Activities in and against Nicaragua, Nicaragua v. United States of America, Merits, Judgment, I.C.J. Reports 1986.

Oeter, Stefan, 'Neutrality and Alliances,' in Vattel's International Law from a XXIst Century Perspective / Le Droit international de Vattel vu du XXIe siècle, ed. Vincent Chetail and Peter Haggenmacher (Leiden: Brill, 2011), 335-352.

Onuf Nicholas, 'Civitas Maxima: Wolff, Vattel and the Fate of Republicanism,' American Journal of International Law 88/2 (1994): 280-303.

Piirimäe, Pärtel, 'Official Historiography and the State in Early Modern Europe,' Storia della storiografia 71/1 (2017): 47-75.

Pufendorf, Samuel, De iure naturae ac gentium libri octo (Lund: Junghans, 1672).

Rech, Walter, Enemies of Mankind: Vattel's Theory of Collective Security (Leiden: Brill, 2013).

Remec, Peter Pavel, The Position of the Individual in International Law according to Grotius and Vattel (The Hague: Martinus Nijhoff, 196o).

Silvestrini, Gabriella, 'Justice, War and Inequality. The Unjust Aggressor and the Enemy of the Human Race in Vattel's Theory of the Law of Nations,' Grotiana 31 (2010):44-68.

Skinner, Quentin, From Humanism to Hobbes: Studies in Rhetoric and Politics (Cambridge: Cambridge University Press, 2018).

Straumann, Benjamin, Roman law in the state of nature: The Classical Foundations of Hugo Grotius' Natural Law (Cambridge: Cambridge University Press, 2015).

Toyoda, Tetsuya, Theory and Politics of the Law of Nations: Political Bias in International Law Discourse of seven German Court Councilors in the Seventeenth and Eighteenth Centuries (Leiden: Martinus Nijhoff Publishers, 2011).

Vattel, Emer de, Le loisir philosophique ou pieces diverses de philosophie, de morale et d'amusement (Dresde: George Conrad Walther, 1747).

Vattel, Emer de, Mémoires pour server à l'histoire de notre tems, par l'Observateur hollandois [Jacob-Nicolas Moreau], rédigez et augmentez par M. D. V. [Emer de Vattel] (Frankfort and Leipzig: Aux Dépens de la Compagnie, 1757).

Vattel, Emer de, Mémoires pour servir à l'histoire de notre tems, par rapport à la guerre anglo-gallicane, par l'Observateur hollandois [Jacob-Nicolas Moreau], rédigez et augmentez par M. D. V. [Emer de Vattel], 2 vols. (Frankfurt and Leipzig: aux dépens de la compagnie, $1757-1758$ ).

Vattel, Emer de, The Law of Nations, or Principles of the Law of Nature, Applied to the Conduct and Affairs of Nations and Sovereigns, with Three Early Essays on the Origin and Nature of Natural Law and on Luxury (Indianapolis, IN: Liberty Fund, 2008).

Wolff, Christian, Jus gentium methodo scientifica pertractata (Halle: Renger, 1749).

Wood, Michael, First Report on the Formation and of Customary International Law, International Law Commission 65th Session, A/CN.4/663. 
Zurbuchen, Simone, 'Emer de Vattel on the Society of Nations and the Political System of Europe,' in System, Order and International Law: the Early History of International Thought from Machiavelli to Hegel, ed. Stephan Kadelbach, Thomas Kleinlein and David Roth-Isigkeit (Oxford: Oxford University Press, 2017), 263-382.

Zurbuchen, Simone, 'Vattel's Law of Nations and the Principle of Non-Intervention,' Grotiana 31 (2010): 69-84. 